\title{
THE INFLUENCE OF CULTIVATION TEMPERATURE ON SOME PHENOTYPIC TRAITS OF YERSINIA PSEUDOTUBERCULOSIS
}

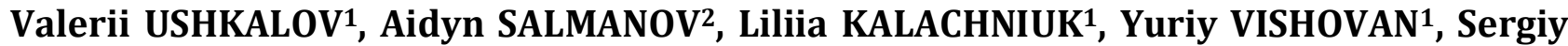 BOIANOVSKIY ${ }^{1}$, Artem USHKALOV ${ }^{3}$, Andry GRANATE ${ }^{1}$, Goma M. HUWIAGE ${ }^{4}$, Oleksandra KEPPLE ${ }^{1}$}

${ }^{1}$ National University of Life and Environmental Sciences of Ukraine, Ukrainian Laboratory of Quality and Safety of Agricultural Products

${ }^{2}$ Shupyk National Medical Academy of Postgraduate Education, Ukrainian National Committee of Infection Control (UCIC) and Antimicrobial Resistance (UCAST)

${ }^{3}$ Main administration of state service of Ukraine on food safety and consumer protection in Kharkov region

${ }^{4}$ High Institute of Medical Science \& Technology, Algarabolli, Libya

Corresponding author: Valerii Ushkalov, e-mail: ushkalov63@gmail.com

DOI: $10.38045 /$ ohrm.2020.1.14

UDC: 616.98:578.834.1(478)

Keywords: Yersinia pseudotuberculosis, cultivation temperature, phenotypic traits, antibiotics, resistance, sensitivity, biofilms.

Cuvinte cheie: Yersinia pseudotuberculosis, temperatura de cultivare, trăsături fenotipice, antibiotice, rezistență, sensibilitate, biofilme.
Introduction. Some causative agents of sapro-zoonotic infections can multiply in the external environment (water reservoirs, soils, plants), as well as in animals, including microorganisms of the genus Yersinia.

Material and methods. Isolation and identification of Y. pseudotuberculosis was carried out in accordance with the instructions on "Epidemiology, laboratory diagnosis of yersiniosis, organization and conduct of preventive and anti-epidemiological measures". Antibiotic sensitivity was performed via the disc diffusion method in accordance with EUCAST and national guidelines. Biofilm formation was tested using the spectrophotometric assay.

Results. It was established that the studied cultures showed a decrease in the level of saccharolytic activity during cultivation at a temperature of $+37^{\circ} \mathrm{C}$ in comparison with the results obtained at $25^{\circ} \mathrm{C}$, changes in sensitivity to antibiotics depending on the temperature of cultivation were revealed. It was established that $Y$. pseudotuberculosis cultures were able to form denser ( $\lambda$ 570) biofilms when cultured at $25^{\circ} \mathrm{C}$, in comparison with biofilms formed at $37^{\circ} \mathrm{C}$.

Conclusions. Biological characteristics of the studied Y. pseudotuberculosis isolates (changes in the saccharolytic activity, the level of sensitivity to antibiotics and the formation of biofilms were revealed) depends on the cultivation conditions.

INFLUENTTA TEMPERATURII DE CULTIVARE ASUPRA UNOR PROPRIETĂȚI FENOTIPICE ALE YERSINIA PSEUDOTUBERCULOSIS

Introducere. Unii agenți cauzali ai sapronozelor se pot multiplica atât în mediul extern (rezervoare de apă, sol, plante), cât și în organismul animalelor, la astfel de agenţi patogeni atribuindu-se și bacteriile din genul Yesinia.

Material și metode. Izolarea și identificarea Y. pseudotuberculosis a fost efectuată în conformitate cu instrucțiunea „Epidemiologia, diagnosticul de laborator al yersiniozei, organizarea și desfășurarea măsurilor preventive și antiepidemice”. Sensibilitatea la antibiotice a fost efectuată prin metoda difuzimetrică, în conformitate cu EUCAST și gidul național. Capacitatea de a forma biofilme, cât și densitatea lor, au fost determinate prin metoda spectrofotometrică după densitatea optică.

Rezultate. Culturile studiate au demonstrat o scădere a nivelului activităţii zaharolitice, în timpul cultivării la temperatura de $+37^{\circ} \mathrm{C}$, în comparație cu rezultatele obținute la $25^{\circ} \mathrm{C}$, totodată înregistrându-se și diferenţe ale sensibilității la antibiotice în funcție de temperatura de cultivare. $S$-a mai stabilit că culturile de Y. pseudotuberculosis au fost capabile să formeze biofilme mai dense ( $\lambda$ 570) la temperatura de $25^{\circ} \mathrm{C}$, decât cele formate la $37^{\circ} \mathrm{C}$.

Concluzii. S-a stabilit că, manifestarea proprietăților biologice ale izolatelor studiate de $Y$. pseudotuberculosis (modificări ale activității zaharolitice, nivelul de sensibilitate la antibiotice și formarea de biofilme) depinde de condițile de cultivare. 


\section{INTRODUCTION}

Some causative agents of sapro-zoonotic infections are capable of reproduction in the external environment (water reservoirs, soils, plants), as well as in the body of animals, including microorganisms of the genus Yersinia. The diseasecausing pathogens occurring in humans and animals Yersinia pestis, Yersinia pseudotuberculosis, and Yersinia enterocolitica are quite common. Yersiniosis is a foodborne gastrointestinal tract zoonotic disease that can be transmitted via contaminated food or water. In Ukraine, there are active natural reservoirs of $Y$. pseudotuberculosis. Bacteriocarrier is recorded among synanthropic and agricultural animals, which determines the source of the pathogen and the factors of its transmission. Contamination of livestock products and/or food causes human diseases. There are evidences, suggesting that Y. pseudotuberculosis serotype $01 \mathrm{~b}$ has been isolated due to intragenomic rearrangements and deletions of $Y$. pestis. The pathogenicity of $Y$. pseudotuberculosis is determined by genes that dictate invasive and cytotoxic properties of the pathogen (1). Therefore, the isolation of pure culture, as well as the identification of $Y$. pseudotuberculosis for a particular serovar, creates the basis for diagnosing pseudotuberculosis.

Pseudotuberculosis is an infectious disease of various animal species, accompanied by intoxication, the formation of caseous nodules and granularnecrotic lesions like tuberculosis in various organs. The disease is characterized by fever, intoxication, damage to the small intestine and liver, scarlet fever-like rash.

The main route of infection is the alimentary one.

Yersinia spp. are bipolar-staining, gram-negative facultative anaerobic bacteria. The optimum cultivation temperature is $28-29^{\circ} \mathrm{C}$, and can vary from 2 to $40^{\circ} \mathrm{C}$. They retain mobility at $22-28^{\circ} \mathrm{C}$ (except $Y$. pestis) and become motionless at $37^{\circ} \mathrm{C}$. It should also be noted that $Y$. enterocolitica has a higher motility compared to other Yersinias. At low temperature conditions $\left(4-8^{\circ} \mathrm{C}\right)$, bacteria form smooth $(\mathrm{S})$ colonies with slow accumulation.

At temperatures above $28^{\circ} \mathrm{C}, Y$. Pseudotuberculosis dissociates into a rough (R) form. When isolated from the body of the patient or from animals, $Y$. pseudotuberculosis and $Y$. enterocolitica exhibit an S-form. However, sometimes, the cultures of $Y$. pseudotuberculosis are isolated in R, SR-, R-S-forms (1, 2).

Demidova GV, Zyuzina VP, et al. (2009) examined the pathogenic strains of $Y$. pseudotuberculosis and found that, due to their sensitivity to polymyxin $B$, the studied strains, belonging to different serotypes can be divided into groups, particularly in cultures of serotypes I and IV, which were sensitive to polymyxin $\mathrm{B}$ at $28^{\circ} \mathrm{C}$ and resistant to $37^{\circ} \mathrm{C}(3)$.

Titareva GM, Fursova NK, Balakhonov SV. (2003) examined strains of $Y$. pestis and reported that the strain resistance, cultured at $25^{\circ} \mathrm{C}$ is higher than that of strains cultured at $37^{\circ} \mathrm{C}$. Therefore, the study of the biological properties of cultures under incubation temperature conditions of 23 $28^{\circ} \mathrm{C}$ and $37^{\circ} \mathrm{C}$ is an important feature of the differential diagnosis of Yersinia spp. (4). The ability to form biofilms is considered as a factor providing selective advantages of microorganisms in biological niches (according to CDC data, nearly $80 \%$ of human bacterial infections are caused by polymicrobial biofilms) $(5,6)$. The aim of the study was to study the biological properties of $Y$. pseudotuberculosis strains.

\section{MATERIAL AND METHODS}

The study carried out the Y. pseudotuberculosis isolation and identification in accordance with "Epidemiology, laboratory diagnosis of yersiniosis, the organization and conduct of preventive and anti-epidemiological measures" instructions (7). Five cultures of $Y$. pseudotuberculosis were investigated, which have been observed in synanthropic rodents.

The morphological features and mobility of Yersinia cultures were determined according to the instructions (7). The morphological features were determined via microscope of Gramstained smears. To determine the motility of bacteria, preparations such as "crushed drop" were prepared from daily agar cultures grown at $23^{\circ} \mathrm{C}$ and $37^{\circ} \mathrm{C}$.

The enzymatic properties such as the ability of microorganisms to form acetyl methyl carbinol (acetoin) during glucose fermentation in the Foges-Proskauer reaction were determined; phenylalanine deaminase, the capacity for esculin hydrolysis, indole/urea, urease and ornithine de carboxylase were detected; the saccha- 
rolytic properties on the Hiss medium with sugars were also revealed.

Antimicrobial susceptibility testing was performed using the EUCAST disk diffusion method. (version 10) and MU on "Determination of microorganisms susceptibility to antibacterial drugs" (MOH, 2007) $(8,9)$.

The ability of isolates to form biofilm (by method C. C. Heilmann E, 1996) and the biofilm optical density indexes (by spectrophotometrically) in three cultures of $Y$. pseudotuberculosis were evaluated, as well as in Pasteurella multocida, Salmonella Typhimurium, and Salmonella Enteritidis, $E$. coli, $S$. aureus $(10,11)$ under different cultivation regimes $\left(25^{\circ} \mathrm{C}\right.$ and $\left.37^{\circ} \mathrm{C}\right)$.

The nutrient media, commercial tests, and discs with antimicrobial drugs manufactured by HiMedia were used within the study.

\section{RESULTS}

The morphological features of the obtained cultures, as well as the motility in a "crushed drop" type drug have been determined via the microscope of the Gram-stained smears. To determine the bacterial motility, the one-day agar cultures have been prepared under two cultivation regimes $\left(23^{\circ} \mathrm{C}\right.$ and $\left.37^{\circ} \mathrm{C}\right)$.
Over 24 hours, reddish transparent convex (sometimes greyish-yellow oily colonies with $0.5-1 \mathrm{~mm}$ diameter), and granular or tubular colonies of S-, O- and R-forms are formed on meatand-peptone agar, Endo agar, blood agar. The Sforms were represented by smooth, convex colonies. The R-forms had granular colonies with darkened center and thin lace-type periphery; this pattern was also found in the pathogen of zoonotic plague (camel plague).

The gram-negative organisms of ovoid (coccoidlike) form (0.8-5.0 $\mu \mathrm{m}$ length, $0.4-0.8 \mu \mathrm{m}$ width), as well as the organisms with rounded tails (1.5$6 \mu \mathrm{m}$ length, $0.4-0.8 \mu \mathrm{m}$ width) were observed in the smears. Some bacterial cultures exhibited bipolarity properties. The study of motility in cultures showed that they were stationary at $37^{\circ} \mathrm{C}$ and mobile at $23^{\circ} \mathrm{C}$.

Studies of bacterial enzyme properties showed that the studied cultures did not exhibit the ability to form acetyl methyl carbinol in the FogesProskauerre action at $+23^{\circ} \mathrm{C}$ and $+37^{\circ} \mathrm{C}$; they hydrolyzed the esculin and did not form phenylpyruvic acid (determination of phenylalanine deaminase) and ornithine decarboxylase (tab. 1). A decrease in saccharolytic activity of the cultures was recorded when cultivated at $+37^{\circ} \mathrm{C}$ (doubtful reaction).

Table 1. Enzymatic properties of Y. pseudotuberculosis.

\begin{tabular}{|c|c|c|c|c|c|c|c|c|c|c|c|c|c|c|c|c|c|c|c|}
\hline \multirow{3}{*}{$\frac{\mathscr{d}}{\stackrel{\pi}{0}}$} & \multicolumn{19}{|c|}{ Enzymatic properties } \\
\hline & \multicolumn{2}{|c|}{ Mobility } & \multirow{2}{*}{ 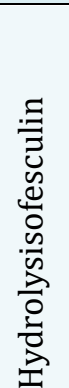 } & \multirow{2}{*}{$\begin{array}{l}\stackrel{\Xi}{\Xi} \\
\frac{\pi}{\pi} \\
\frac{\pi}{2} \\
\frac{d}{2}\end{array}$} & \multirow{2}{*}{ 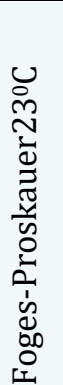 } & \multirow{2}{*}{\multicolumn{2}{|c|}{ 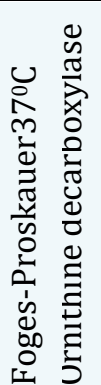 }} & \multicolumn{2}{|c|}{ 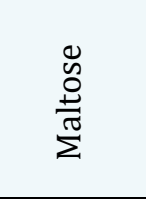 } & \multicolumn{2}{|c|}{ 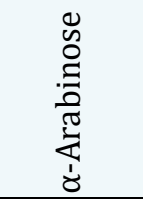 } & \multicolumn{2}{|c|}{ 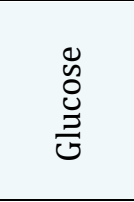 } & \multicolumn{2}{|c|}{ 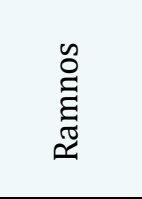 } & \multicolumn{2}{|c|}{ 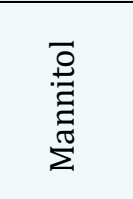 } & \multicolumn{2}{|c|}{ 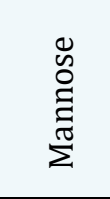 } \\
\hline & $\begin{array}{l}\text { Uু } \\
\text { ָৃ }\end{array}$ & $\underset{n}{\stackrel{\aleph}{n}}$ & & & & & & $\underset{\stackrel{N}{N}}{\stackrel{\cup}{ }}$ & 芩 & 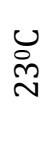 & $\begin{array}{l}\stackrel{0}{ } \\
\text { m }\end{array}$ & 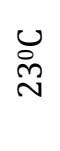 & $\underset{m}{\stackrel{一}{\circ}}$ & 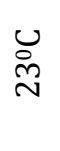 & $\begin{array}{l}\stackrel{0}{\circ} \\
\text { m }\end{array}$ & $\begin{array}{l}\stackrel{\sim}{N} \\
\stackrel{\text { N }}{ }\end{array}$ & 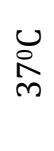 & $\begin{array}{l}\text { Ů } \\
\text { ָे }\end{array}$ & 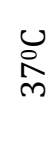 \\
\hline Y. p 1 & + & - & + & - & - & - & - & + & \pm & + & \pm & + & \pm & + & \pm & + & \pm & + & \pm \\
\hline Y.p 2 & + & - & + & - & - & - & - & + & \pm & + & \pm & + & \pm & + & \pm & + & \pm & + & - \\
\hline Y.p 3 & + & - & + & - & - & - & - & + & \pm & + & \pm & + & \pm & + & \pm & + & \pm & + & \pm \\
\hline Y.p 4 & + & - & + & - & - & - & - & + & \pm & + & \pm & + & \pm & + & \pm & + & \pm & + & - \\
\hline Y.p 5 & + & - & + & - & - & - & - & + & \pm & + & \pm & + & \pm & + & \pm & + & \pm & + & - \\
\hline
\end{tabular}

Antibiotic resistance was determined in $5 \mathrm{ob}-$ tained isolates via the disc diffusion method (tab. 2 ), and the results were interpreted according to
EUCAST (version 10) and MU on "Determination of microorganism susceptibility to antibacterial drugs" (MOH, 2007). 
Table 2. Susceptibility to antibacterial drugs Y.pseudotuberculosis.

\begin{tabular}{|c|c|c|c|c|c|c|c|c|c|c|}
\hline \multirow{2}{*}{$\begin{array}{c}\text { The name of the } \\
\text { drug }\end{array}$} & \multicolumn{6}{|c|}{ Y.pseudotuberculosis, diameter of crop growth inhibition, $\mathrm{mm}$, (n = 5) } \\
\cline { 2 - 12 } & $23^{\circ} \mathrm{C}$ & $37^{\circ} \mathrm{C}$ & $23^{\circ} \mathrm{C}$ & $37^{\circ} \mathrm{C}$ & $23^{\circ} \mathrm{C}$ & $37^{\circ} \mathrm{C}$ & $23^{\circ} \mathrm{C}$ & $37^{\circ} \mathrm{C}$ & $23^{\circ} \mathrm{C}$ & $37^{\circ} \mathrm{C}$ \\
\hline $\begin{array}{c}\text { Piperacillin } \\
<17 ; 20 \leq ;\end{array}$ & 35 & 26 & 34 & 25 & 34 & 28 & 28 & 20 & 37 & 28 \\
\hline $\begin{array}{c}\text { Ampicillin } \\
<14 ; 14 \leq ;\end{array}$ & 31 & 17 & 30 & 16 & 20 & 11 & 13 & 6 & 20 & 11 \\
\hline $\begin{array}{c}\text { Cefalexin } \\
<14 ; 14 \leq ;\end{array}$ & 31 & 23 & 30 & 22 & 36 & 24 & 28 & 20 & 28 & 20 \\
\hline $\begin{array}{c}\text { Cefuroxime } \\
<19 ; 19 \leq ;\end{array}$ & 31 & 24 & 30 & 23 & 28 & 21 & 30 & 22 & 30 & 23 \\
\hline $\begin{array}{c}\text { Cefotaxime } \\
<17 ; 20 \leq ;\end{array}$ & 37 & 23 & 36 & 22 & 32 & 23 & 28 & 20 & 36 & 22 \\
\hline $\begin{array}{c}\text { Ceftriaxone } \\
<22 ; 25 \leq ;\end{array}$ & 40 & 30 & 40 & 30 & 34 & 25 & 34 & 25 & 34 & 25 \\
\hline $\begin{array}{c}\text { Cefepime } \\
<24 ; 27 \leq ;\end{array}$ & 22 & 22 & 21 & 21 & 34 & 34 & 26 & 26 & 28 & 28 \\
\hline $\begin{array}{c}\text { Imipenem } \\
<17 ; 22 \leq ;\end{array}$ & 24 & 24 & 24 & 24 & 36 & 36 & 30 & 30 & 32 & 32 \\
\hline $\begin{array}{c}\text { Meropenem } \\
<16 ; 22 \leq ;\end{array}$ & 22 & 36 & 23 & 37 & 24 & 36 & 28 & 40 & 24 & 37 \\
\hline $\begin{array}{c}\text { Gentamicin } \\
<17 ; 17 \leq ;\end{array}$ & 22 & 22 & 23 & 23 & 24 & 24 & 26 & 26 & 28 & 28 \\
\hline Nalidixic acid & 30 & 30 & 31 & 31 & 36 & 36 & 42 & 42 & 30 & 30 \\
\hline $\begin{array}{c}\text { Ciprofloxacin } \\
<22 ; 25 \leq ;\end{array}$ & 30 & 30 & 31 & 31 & 26 & 40 & 34 & 34 & 34 & 34 \\
\hline $\begin{array}{c}\text { Norfloxacin } \\
<22 ; 22 \leq ;\end{array}$ & 26 & 34 & 27 & 35 & 32 & 40 & 20 & 28 & 30 & 38 \\
\hline $\begin{array}{c}\text { Ofloloxacin } \\
<22 ; 24 \leq ;\end{array}$ & 34 & 43 & 36 & 38 & 26 & 43 & 30 & 38 & 26 & 36 \\
\hline $\begin{array}{c}\text { Levofloxacin } \\
<19 ; 23 \leq ;\end{array}$ & 30 & 26 & 32 & 36 & 22 & 26 & 30 & 40 & 40 & 35 \\
\hline $\begin{array}{c}\text { Chloramphenicol } \\
<17 ; 17 \leq ;\end{array}$ & 32 & 23 & 31 & 20 & 23 & 20 & 30 & 21 & 30 & 20 \\
\hline Polymyxin B & 6 & 16 & 6 & 18 & 6 & 16 & 6 & 12 & 6 & 6 \\
\hline
\end{tabular}

The examined cultures were predominantly sensitive to penicillins, cephalosporins, carbapenems, quinolones, gentamicin, and chloramphenicol, both at $+23^{\circ} \mathrm{C}$ and at $+37^{\circ} \mathrm{C}$. Individual cultures exhibited resistance (Y. p 4 to Ampicillin; Y. p 1 and Y. p 2 to Cefepime) and moderate resistance (Y. p 4 to Cefepime) under given conditions.

The cultures of Y.p 3 and Y. p 5 exhibited sensitivity to Ampicillin at $+23^{\circ} \mathrm{C}$ and resistance at $+37^{\circ} \mathrm{C}$. At $+23^{\circ} \mathrm{C}$, a culture Y. p 4 showed resistance to Norfloxacin. The Y. p 3 culture showed moderate level of resistance to Levofloxacin at $+23{ }^{\circ} \mathrm{C}$ but remains uniformly susceptible to it at $+37^{\circ} \mathrm{C}$.
The culture sensitivity to Cefepime, Imipenem, Gentamicin, Nalidixic acid was the same under the given temperature conditions. In general, most bacterial cultures demonstrated changes in drugs susceptibility depending on temperature conditions. Thus, the lower level of bacterial susceptibility was recorded at $+37^{\circ} \mathrm{C}$ - to Piperacillin, Ampicillin, Cefalexin, Cefuroxime, Cefotaxime, Ceftriaxone, Chloramphenicol and at $23^{\circ} \mathrm{C}$ - to Meropenem, Norfloxacin, Ofloxacin, Levofloxacin, Polymyxin B.

The ability to form biofilms and their density (tab. 3) were determined in Y. pseudotuberculosis cultures (Y.p 1, Y. p 2, Y. p 3) at $25^{\circ} \mathrm{C}$ (S-form) and $37^{\circ} \mathrm{C}$ (R-form); the obtained results were compared with similar indicators of Pasteurella 
multocida culture (cultivation on heart-brain broth (HBB)), as well as Salmonella Typhimurium and Salmonella Enteritidis (cultivation on meat-peptone broth (MPB), E. coli (STX2) and associated E. coli culture (STX2) + Proteus mirabilis (cultivation on MPB), $S$. aureus (cultivation on tryptone-soy broth (TSB)).

Table 3. Indicators of biofilm optical density produced by cultures under different cultivation conditions.

\begin{tabular}{|c|c|c|c|c|c|}
\hline Culture & 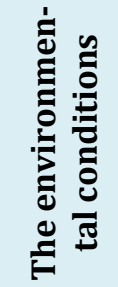 & 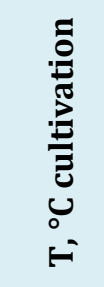 & 足 & 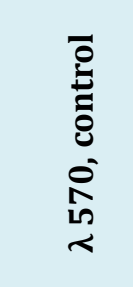 & $\begin{array}{c}\text { actual value } \\
(\lambda 570-\lambda 570 \text { control })\end{array}$ \\
\hline \multirow{2}{*}{ Y. p 1} & \multirow{6}{*}{ MPB } & $25^{\circ} \mathrm{C}$ & 2.8781 & \multirow{6}{*}{0.1423} & 2.7358 \\
\hline & & $37^{\circ} \mathrm{C}$ & 1.6416 & & 1.4993 \\
\hline \multirow{2}{*}{ Y. p2 } & & $25^{\circ} \mathrm{C}$ & 2.9901 & & 2.8478 \\
\hline & & $37^{\circ} \mathrm{C}$ & 1.6734 & & 1.5311 \\
\hline \multirow{2}{*}{ Y.p 3} & & $25^{\circ} \mathrm{C}$ & 3.6737 & & 3.5314 \\
\hline & & $37^{\circ} \mathrm{C}$ & 1.4557 & & 1.3134 \\
\hline \multirow{2}{*}{ P. multocida } & \multirow{4}{*}{ SMB } & $25^{\circ} \mathrm{C}$ & 1.4218 & \multirow{4}{*}{0.2244} & 1.1974 \\
\hline & & $37^{\circ} \mathrm{C}$ & 2.5968 & & 2.3734 \\
\hline S. Typhimurium & & $37^{\circ} \mathrm{C}$ & 0.9048 & & 0.6804 \\
\hline$S$. Enteritidis & & $37^{\circ} \mathrm{C}$ & 1.1209 & & 0.8965 \\
\hline E. coli & \multirow{2}{*}{ MPB } & $37^{\circ} \mathrm{C}$ & 0.3798 & 0.1423 & 0.2375 \\
\hline E. coli+P. mirabilis & & $37^{\circ} \mathrm{C}$ & 1.3265 & 0.1423 & 1.1842 \\
\hline S. aureus & TSB & $37^{\circ} \mathrm{C}$ & 4.6778 & 0.3719 & 4.3049 \\
\hline
\end{tabular}

$Y$. pseudotuberculosis were reported to form biofilms. All studied bacterial cultures (S colonies) formed high density bacterial associations at $25^{\circ} \mathrm{C}$ (Y. p1 - $\lambda 2.8781$, Y. p2 - $\lambda 2.9901$, Y. p3 $\lambda$ 3.6737). When cultured at $37^{\circ} \mathrm{C}$ (in $\mathrm{R}$-form), the biofilm optical density was significantly lower (Y. p1 - $\lambda$ 1.6416, Y.p2 - $\lambda 1.6734$, Y. p3 - $\lambda$ $1.4557)$, which is respectively $45.2 \%, 46.2 \%$, $62.8 \%$ of the optical density of the cultures at $25^{\circ} \mathrm{C}$.

The evaluation of the optical density in other cultures (S colonies) showed significantly lower optical densities of biofilms compared to cultures of $Y$. pseudotuberculosis, namely in $S$. Typhimurium $-\lambda 0,6804, S$. Enteritidis $-\lambda$ 0.8965 , E. coli $\lambda-0.2375$, and in the associated culture of E. coli 0723 (STX2) + Proteus mirabilis $\lambda-1.1842$, which was $23.89 \%, 31.48 \%, 8.34 \%$, and $41.58 \%$ respectively, from the optical density index of the S-shaped culture (at $25^{\circ} \mathrm{C}$ ) $Y$. pseudotuberculosis 2 ( $\lambda$ 2.8478).

The coagulase-positive culture of $S$. aureus formed a much higher density biofilm than $Y$. pseudotuberculosis cultures. The optical density of $S$. aureus was $\lambda$ 4.3049, which made up $151.17 \%$ of optical density (at $25^{\circ} \mathrm{C}$ ) Y. pseudotuberculosis $2(\lambda 2,8478)$.

The ability to form biofilms in P. multocida cultures was slightly lower than in Y. pseudotuberculosis cultures. At $25^{\circ} \mathrm{C}$ and $37^{\circ} \mathrm{C}$, the optical density of $P$. multocida cultures were $\lambda 1.1974$ and $\lambda 2.3734$, respectively, that is, at $25^{\circ} \mathrm{C}$ the $P$. multocida optical density was $50.5 \%$ of that of $P$. multocida at $37^{\circ} \mathrm{C}$.

\section{DISCUSSIONS}

The obtained results proved that the studied cultures of $Y$. pseudotuberculosis didn't show the ability to form acetyl methyl carbinol at $+23^{\circ} \mathrm{C}$ and $+37^{\circ} \mathrm{C}$; they hydrolyzed the esculin and did not form phenyl pyruvic acid and ornithine decarboxylase; a constant decrease in the level of saccharolytic activity of cultures was observed during cultivation at $+37^{\circ} \mathrm{C}$.

An analysis of the results showed that, Y. pseudotuberculosis antibiotic susceptibility changes to 
most drugs depending on the cultivation temperature, decrease of sensitivity level to Piperacillin, Ampicillin, Cefalexin, Cefuroxime, Cefotaxime, Ceftriaxone, Chloramphenicolwasrecorded, and at $23^{\circ} \mathrm{C}$ - to Meropenem, Norfloxacin, Ofloloxacin, Levofloxacin, Polymyxin B at $+37^{\circ} \mathrm{C}$.

Biofilm formation is regarded as a pathogenicity factor. This study investigated the ability to form biofilmsin Y. pseudotuberculosis cultures compared with Pasteurella multocida, S. Typhimurium, $S$. Enteritidis, E. coli, S. aureus.
The obtained isolates of Y. Pseudotuberculosis were capable to form denser bacterial biofilms at cultivation temperature of $25^{\circ} \mathrm{C}$. At $25^{\circ} \mathrm{C}$ and $37^{\circ} \mathrm{C}$, the Pasteurella multocida culture (S colonies), whereas at $37^{\circ} \mathrm{C}$, it formed a denser biofilm. The biofilm-forming capacity of Y. Pseudotuberculosis cultures ( $\mathrm{S}$ and $\mathrm{R}$ colonies) to form biofilms is higher than S-form in other studied cultures of enterobacteria ( $S$. Typhimurium, $S$. Enteritidis, E. Coli) and Pasteurella multocida, compared to the culture of coagulase-positive $S$. aureus.

\section{CONCLUSIONS}

1. It was established that the manifestation of the biological properties of the studied Y. pseudotuberculosis isolates (in particular, changes in the saccharolytic activity, antibiotic susceptibility and biofilm formation capacity were revealed) depends on the cultivation conditions.

2. The obtained isolates of $Y$. pseudotuberculosis were able to form denser bacterial biofilms at a culture temperature of $25^{\circ} \mathrm{C}$, compared with the formation of biofilms at cultivation temperature $+37^{\circ} \mathrm{C}$.

3. The biofilm-forming capacity Y. pseudotuberculosis cultures ( $\mathrm{S}$ and R colonies) is higher than S-form in other studied cultures of enterobacteria (S. Typhimurium, S. Enteritidis, E. Coli) and Pasteurella multocida, compared to the culture of coagulase-positive $S$. aureus.

\section{CONFLICT OF INTERESTS}

All authors declare no competing interests.

\section{ACKNOWLEDGMENT}

Research was carried out with the financial support of the Ministry of Education and Science of Ukraine.

\section{REFERENCES}

1. Samujlenko AJa. Iersiniozy [Yersiniosis]. In: Samujlenko A Ja, Grin' SA, Eremec VI, et al. Infekcionnaja patologija zhivotnyh [Infectious pathology of animals]. Moskva: RASHN; 2009.

2. Gavrilov KE, Serebrjakova EV, Dunjasheva TJu, Zajceva NN, Eremenko JuD, Lobastov VS, et al. Biologicheskie i fiziko-himicheskie svojstva kul'tur Yersinia pseudotuberculosis v dinamike glubinnogo vyrashhivanija pri razlichnyh temperaturah [Biological and physicochemical properties of Yersinia pseudotuberculosis cultures in the dynamics of submerged cultivation at different temperatures]. Problemy osobo opasnyh infekcij. 2010; 104:49-52.

3. Demidova GV, Sokolova EP, Zjuzina VP, Rykova VL, Morozova IV, Podladchikova ON, et al. Vlijanie vne hromosomnyh jelementov nasledstvennosti na toksicheskie svojstva Yersiniapestis [Influence of non-chromosomal elements of heredity on the toxic properties of Yersiniapestis]. Zhurn. Mikrobiol. 2017;2:28-33.
4. Titareva GM, Fursova NK, Balahonov SV. Shtammovye otlichija Yersinia pestis po chuvstvitel'nosti $\mathrm{k}$ baktericidnomu dejstviju polimiksina [Strain differences of Yersinia pestis in sensitivity to the bactericidal effect of polymyxin]. Uspehi sovremennogo estestvoznanija. 2003;10:100-110. Available from: http://www.natural-sciences.ru/ru/article/ view?id=15147 [Accessed 3th April 2020].

5. Muhsin J, Wisal A, Saadia A, Fazal J, Muhammad I, Muhammad AN, et al. Bacterial biofilm and associated infections. Journal of the Chinese Medical Association. 2018;81(1):7-11. doi:10.1016/j.jcma. 2017.07.012

6. Ghannooum N, Parsek M, Whitely M, Mukherjee PK. Microbial biofilms. Emerg Infect Dis. 2016. DOI: 10.3201/eid2206.160282

7. Minzdrav SSSR vid 30.10.1990, N 15-6/42), MU 3.1.1.2438-09 «Jepidemiologicheskij nadzor i profilaktika psevdotuberkuleza i kishechnogo iersinioza [Epidemiological surveillance and prevention of pseudotuberculosis and intestinal yersiniosis]» (Moskva, 2010).

8. Eucast. The european committee on antimicrobial susceptibility testing (2020). Available from: http://www.eucast.org/ [Accessed 10th February 2020].

9. Ministry of health of Ukraine. Determination of susceptibility of microorganisms to antibacterial drugs (2009). Available from: https://zakon.rada. gov.ua/rada/show/v0167282-07 [Accessed 10th February 2020]. 
10.Srdjan S, Vukovic D, Holá V, Bonaventura G, Djukić S, Cirković I, Filip R. Quantification of biofilm in microtiter plates: overview of testing conditions and practical recommendations for assessment of biofilm production by Staphylococci. APMIS: acta pathologica, microbiologica, et immunologica Scandinavica. 2007;115(8):891-9. DOI:10.1111/ j.1600-0463.2007.apm_630. x

Date of receipt of the manuscript: 03/04/2020

Date of acceptance for publication: 30/05/2020
11.Turko, I., \& Ushkalov, V. (2018). Biofilm-forming ability of coccus forms of the caecal microflora of laying hens when using the probiotic and nanonutrition cobalt. Scientific Messenger of LNU of Veterinary Medicine and Biotechnologies. Series: Veterinary Sciences, 20(87):60-64. DOI: 10.15421/ nvlvet8712

Valerii USHKALOV, ORCID: 0000-0001-5694-632X, SCOPUS Author ID: 36130483300, Web of Science ID researcher AAS-4217-2020

Aidyn SALMANOV, ORCID: 0000-0002-4673-1154, SCOPUS Author ID: 56964145900

Liliia KALACHNIUK, ORCID: 0000-0002-5545-8495, SCOPUS Author ID: 6602997554, Web of Science Researcher ID: M-5019-2018

Yuriy VISHOVAN, ORCID: 0000-0003-1128-593X

Sergiy BOIANOVSKIY, ORCID: 0000-000204621-5192

Artem USHKALOV, ORCID: 0000-0001-8317-7909

Andry GRANATE, ORCID: 0000-0003-3273-903X

Goma M. HUWIAGE, ORCID: 0000-0002-2727-148X

Oleksandra KEPPLE, ORCID: 0000-0002-8123-3310 